MR. OLIVER FRANKLIN (Orcid ID : 0000-0002-4368-2027)

DR MICHAEL B MORRISSEY (Orcid ID : 0000-0001-6209-0177)

Article type : Research Papers

\title{
Natural selection for body shape in resource polymorphic Icelandic Arctic charr
}

Abbreviated title: Shape selection in resource polymorphisms

OLIVER D. FRANKLIN ${ }^{1^{*}}$, SKÚLI SKÚLASON ${ }^{2}$, MICHAEL B. MORRISSEY ${ }^{3}$, \& MOIRA M. FERGUSON ${ }^{1}$

1: Department of Integrative Biology, University of Guelph, Guelph, Ontario, N1G 2W1, Canada

2: Department of Aquaculture and Fish Biology, Hólar University College, Saudárkrókur 551, Iceland

3: Dyers Brae House, School of Biology, University of St. Andrews, St. Andrews, KY18 9TH, UK

* Corresponding author: Oliver Franklin, Department of Integrative Biology, University of Guelph, Guelph, Ontario, N1G 2W1, Canada. Tel: +1 647949 6490, Fax: +1 519767 1656, email: odf@outlook.com

\section{Acknowledgements}

We are grateful to C. Caruso, B. Robinson, and the anonymous reviewers who provided constructive input, and we would like to thank A. Karvonen, B. Kristjánsson, S. Snorrason, S. Colborne, and S.

Campana for valuable contributions in making this study possible. For dedicated assistance in the lab and field, we thank M. Brachmann, C. Ouellet, S. Rieder, J. Flatt, J. Lambelain, and P. Válek, and we thank Jói and Rósa Jonsson for their generosity at Mjóanes. Funding for this study was provided by Natural Sciences and Engineering Research Council of Canada and the Madame Vigdís Finnbogadóttir Scholarship.

This article has been accepted for publication and undergone full peer review but has not been through the copyediting, typesetting, pagination and proofreading process, which may lead to differences between this version and the Version of Record. Please cite this article as doi: $10.1111 /$ jeb. 13346

This article is protected by copyright. All rights reserved. 


\section{Abstract}

Resource polymorphisms exhibit remarkable intraspecific diversity and in many cases are expected to be maintained by diversifying selection. Phenotypic trade-offs can constrain morphologically intermediate individuals from effectively exploiting both alternate resources, resulting in ecological barriers to gene flow. Determining if and how phenotypic trade-offs cause fitness variation in the wild is challenging because of phenotypic and environmental correlations associated with alternative resource strategies. We investigated multiple pathways through which morphology could affect organismal performance, as measured by growth rate, and whether these effects generate diversifying selection in polymorphic Icelandic Arctic charr (Salvelinus alpinus) populations. We considered direct effects of morphology on growth and indirect effects via trophic resource use, estimated by stable isotopic signatures, and via parasitism associated with trophic resources. We sampled over three years in (lakes) Thingvallavatn and Vatnshlíðarvatn using the extended selection gradient path analytical approach and estimating size-dependent mortality. We found evidence for diversifying selection only in Thingvallavatn: more streamlined and terminally-mouthed planktivore charr experienced greater growth, with the opposite pattern in small benthic charr. However, this effect was mediated by parasitism and non-trophic pathways, rather than trophic performance as often expected. Detection of between-morph differences in the presence (Vatnshlíđarvatn) and direction (Thingvallavatn) of size-dependent mortality, together with non-trophic effects of shape, suggest that a morphological trophic performance explanation for polymorphism is insufficient. This rare insight into selection during early diversification suggests that a complex of interacting local factors must be considered to understand how phenotype influences fitness, despite morphological variation reflecting intuitive trade-off explanations.

Keywords: microevolution, phenotypic selection, path analysis, selection differential, performance gradients, adaptation, natural selection, intraspecific competition, sympatric diversification 


\section{Introduction}

Numerous taxa show dramatic phenotypic polymorphisms, many of which involve the specialisation of discrete intraspecific morphs toward use of alternative resources (e.g. Price, 1987; Smith \& Skúlason, 1996; Martin \& Pfennig, 2010). Natural selection is thought to contribute to resource polymorphisms such as where morphs consume alternate resources but intermediate morphologies suffer reduced relative fitness due to incompatibilities between shape and either resource (Smith \& Skúlason, 1996; Arnegard et al., 2014). Such diversifying selection, where natural selection increases phenotypic diversity, could maintain discrete morphs through post-zygotic ecological isolation (Nosil, 2012), and play a role in initiating polymorphisms (Ackermann \& Doebeli, 2004; Herron \& Doebeli, 2013). Studies under semi-natural conditions support a role for diversifying selection in maintaining such morphological diversity (Martin \& Pfennig, 2010; Arnegard et al., 2014) but evidence in the wild is limited due to difficulties estimating fitness, multiple correlated environmental factors, and the numerous pathways through which traits can affect fitness (Mitchell-Olds \& Shaw, 1987; Ghalambor et al., 2003; Morrissey et al., 2010; Franklin \& Morrissey, 2017).

In many cases, morphological specialisation is thought to result adaptively from the effects of traits on fitness where phenotypic trade-offs exist. Phenotypic trade-offs are where a trait that is beneficial for a particular ecological activity is detrimental to performance of an alternative activity (Bolnick et al., 2003). Hypothesised phenotypic trade-offs are typically well-grounded in the scientific literature: for example, lever systems involve force/velocity trade-offs whereby phenotypes maximising jaw closing speed result in weaker closing forces (Wainwright \& Richard, 1995; Herrel et al., 2009). Such biomechanical trade-offs could contribute to diversification where alternate resources demand alternative foraging strategies. However, consideration must also be given to other potential fitness costs associated with alternate ecological activities. For example, exploiting alternate resources may increase susceptibility to predation or parasitism (Langerhans \& Reznick, 2009; Karvonen \& Seehausen, 2012). Recent theory reconciling the general framework of path analysis with the concept of selection gradients now facilitates quantification of the effects of focal

This article is protected by copyright. All rights reserved. 
traits on fitness both directly and indirectly via other traits or performance measures (Morrissey, 2014). In addition to generating estimates of natural selection for focal traits, this approach can reveal through which functional pathway(s) traits influence fitness.

Phenotypic trade-offs are thought to have contributed to the evolution of numerous postglacial fish species (Robinson \& Wilson, 1994; Schluter \& Rambaut, 1996). Trade-offs between terminal and subterminal mouth position affect gape and prey capture ability (Keast \& Webb, 1966; Wainwright \& Richard, 1995), and trade-offs between deep- and streamlined-bodies affect maneuverability and efficiency of continuous swimming (Webb \& Weihs, 1983; Ellerby \& Gerry, 2011). Such morphological trade-offs are expected to constrain individuals to forage on either patchilydistributed pelagic prey or larger benthic prey within a complex substratum, resulting in selection for shape through prey capture efficiency (herein referred to as trophic performance). Arctic charr (Salvelinus alpinus) exhibit variation in morphology and resource-use that is consistent with hypothesised trade-offs associated with benthic and pelagic foraging. Coexisting morphs in Iceland inhabit ecosystems with few interspecific competitors and predators and often overlap in spawning times and locations (Skúlason et al., 1989a; Jónsson \& Skúlason, 2000; Woods et al., 2012). The ability in these systems to gather individual-level data on diet, parasitism, and growth, permits insight into the various pathways through which trade-offs can influence fitness and facilitates estimates of diversifying selection in the wild.

We investigated multiple pathways by which morphology could affect overall organismal performance, as measured by growth rate, and investigated whether these effects generate net diversifying selection in populations of Arctic charr inhabiting two lakes in Iceland in which early stages of putatively adaptive phenotypic differentiation are well-documented. We considered direct effects of morphology on growth, simultaneously with possible indirect effects via habitat preferences (as reflected by stable isotope analysis), and rates of parasitism that we expected would be linked to habitat use. We conducted our analyses of morphology in a geometric morphometrics

This article is protected by copyright. All rights reserved. 
framework, and utilised the extended selection gradient path analytical approach (Morrissey, 2014) to quantify direct and indirect effects of morphology on fitness. We found evidence for diversifying selection in the lake in which greater differentiation already exists, and found that this diversifying selection is largely mediated by parasitism, rather than being an effect of morphology on trophic performance.

\section{Methods}

Study system

We separately investigate two lakes, Thingvallavatn and Vatnshliðarvatn, that contain charr morphs exhibiting differentiation associated with morphological trade-offs. Arctic charr, long recognised for intraspecific diversity (Klemetsen, 2010), exhibit degrees of phenotypic and genetic diversification across Icelandic lakes (Gíslason et al., 1999; Kapralova et al., 2011; Kristjánsson et al., 2011; Woods et al., 2012). Since colonisation 10,000 years ago, many lakes became inaccessible to migrants due to lava flows, landslides and isostatic rebound, and likely experienced no subsequent colonisation (Norddahl \& Einarsson, 2001; Wilson et al. 2004; Geirsdóttir et al., 2009). Thingvallavatn is a spatially complex, spring-fed environment containing four charr morphs, distinguished as benthic or pelagic and further by size (small or large benthic) or diet (planktivore or piscivore), as well as threespine stickleback and brown trout (Jónasson, 1992). The small benthic and planktivore charr on which we focus overlap in spawning times and locations and exhibit morphological differences consistent with expectations for benthic and pelagic niches, respectively (Webb, 1984; Skúlason et al., 1989a;

Wainwright \& Richard, 1995). Vatnshlíđarvatn is a simple, shallow, runoff-fed lake with two charr morphs and no other fish (Jónsson \& Skúlason, 2000). The silver and brown morphs exhibit lifehistory differences and contrast in size and shape associated with the breadth of prey taxa used. The smaller, deeper bodied brown charr is a benthic Cladocera-specialist, while the larger, more streamlined silver charr is a trophic generalist (Jónsson \& Skúlason, 2000; Franklin, 2017). In

This article is protected by copyright. All rights reserved. 
Vatnshlíđarvatn, cannibalism occurs infrequently (Jónsson \& Skúlason, 2000) and avian predators are usually present (personal observation). Morphological differentiation has been considered an adaptation to alternate trophic resources in both lakes (Malmquist et al., 1992; Jónsson \& Skúlason, 2000), and we investigate the lakes separately as two examples of shape selection in resource polymorphisms.

\section{Sampling}

In July 2014, 2015 and 2016, we sampled Arctic charr from specific locations within Thingvallavatn and Vatnshlíđarvatn. In Thingvallavatn we sampled small benthic $(n=359)$ and planktivore $(n=611)$ charr from the littoral zone around Mjóanes peninsula (Sandlund et al., 1992; Kapralova et al., 2011). In Vatnshlíđarvatn we sampled brown $(n=199)$ and silver $(n=943)$ charr along the north shore. We aimed to sample a range of immature charr to capture morphological variation unrelated to sexual traits, using Nordic mixed nets with mesh size 5 to $55 \mathrm{~mm}$. On-site morph classifications, distinguished by size, shape, texture, and colour, were supported by objective classification using Gaussian mixture models (Franklin, 2017).

Fish were sacrificed and, at the laboratory, individuals were weighed, their left sides photographed, and caudal muscle tissue was removed and frozen. Individual fish were frozen until sampling concluded, whereby we thawed them, extracted otoliths, determined their sex, and weighed their gonads. For a random subset of each morph (planktivore $n=349$, small benthic $n=300$, silver $n=$ 489 , brown $\mathrm{n}=123$ ) we quantified Diphyllobothrium spp. in the body cavity and Diplostomum spp. in the right eye, using light microscopy for identification. Caudal muscle tissue was oven-dried at $60^{\circ} \mathrm{C}$ and ground to send 500ug to GLIER, University of Windsor, to quantify $\delta 13 \mathrm{C}$ and $\delta 15 \mathrm{~N}$ stable isotope ratios. Age information was obtained by counting annuli of whole otolith sagittae submerged in water overnight and viewed with reflected light on a dark surface. Where we could not confidently assign fish sex due to underdeveloped gonads (208 fish), we used the male-specific marker sdY and

This article is protected by copyright. All rights reserved. 
procedure described in Yano et al. (2012) to confirm sex. DNA was extracted from caudal muscle tissue and then PCR and agarose electrophoresis were used to identify presence of sdY.

Shape, trophic resource, and performance data

Shape, trophic resource, and performance metrics were required to estimate effects and function of shape within our path analytical hypothesis (Fig. 1a). Our focal morphs differ in life history characteristics, including our performance metric of growth (Malmquist et al., 1992; Jónsson \& Skúlason, 2000). Therefore, to explore natural selection at the most relevant level, path analyses were assessed within each morph. However, to facilitate interpretation of shape selection between coexisting morphs, our shape variables were calculated by pooling coexisting morphs within lakes. Strong covariance of within-morph shape variation with across-morph shape variation suggests that our variables are appropriate summaries of shape to explore within-morph patterns (Franklin, 2017). We therefore have two sets of shape variables, one per lake, because a formal comparison of shape variation between lakes is beyond the scope of this study.

Shape data were summarised in each lake using linear measures of pectoral fin length and geometric morphometric relative warps one (RW1) to five (RW5), which account for around $75 \%$ of shape variation captured by 20 landmarks (Fig. S1; Franklin, 2017). Relative warps, principal components of shape space interpretable as shape transformations along major axes of observed variation, were computed using TPS software (F. James Rohlf; http://life.bio.sunysb.edu/morph), from size- and position- corrected Procrustes scores (as Franklin, 2017). Briefly, the greatest axis of shape variation (RW1T; where T references Thingvallavatn) in Thingvallavatn describes variation in relative head size and elongation of the body, particularly in the caudal region, and variation in mouth position, whereas RW2T reflects mid-body depth. The greatest axis in Vatnshlíđarvatn (RW1V) describes variation in relative head size, with RW2V reflecting depth of body (Fig. 2). In both lakes, coexisting

This article is protected by copyright. All rights reserved. 
morphs can be differentiated by morphology along relative warp axes (Fig. S2, Franklin. 2017).

Although we explored effects of RW1 to RW5 in each lake, here we present results for RW1 and RW2 which differentiate coexisting morphs and represent shape differences consistent with the expected variation in body-shape and mouth-position associated with trophic performance (Malmquist et al., 1992; Jónsson \& Skúlason, 2000; Franklin, 2017). Results for both lakes' RW3 to RW5 are contained in the appendix.

As a performance measure for path analyses, growth was estimated as the increase in backcalculated fork length for the last complete year of growth. This was measured by the most recent full otolith annulus, which relates more directly to observed shape and trophic proxies (below) than lifetime growth. Estimates of back-calculated length-at-age were obtained through relative sizes of otolith annuli, under the assumption that the relationship between somatic and otolith growth is linear throughout the age range in question (Casselman, 1990; Campana \& Jones, 1992). To account for potential bias associated with statistical adjustments (Campana, 1990), we used a biological intercept of length at hatching of $20 \mathrm{~mm}$ and otolith diameter of $0.1 \mathrm{~mm}$ (from Salvelinus malma; Radtke et al. 1996). We backcalculated length-at-age as

$$
L_{i}=L_{c}+\left(O_{i}-O_{c}\right)\left(L_{c}-L_{o}\right)\left(O_{c}-O_{o}\right)^{-1},
$$

where $L_{i}$ is estimated fish fork length at age $i, L_{c}$ is fork length at capture, $O_{i}$ is measured otolith radius at age $i, O_{c}$ is otolith radius of outermost complete band at capture, $L_{o}$ is fork length at biological intercept, and $O_{o}$ is otolith radius at biological intercept, with all lengths in $\mathrm{mm}$. Mean absolute error of observed with backcalculated size at age, calculated as $\left(L_{i}-L_{c}\right) / L_{c} * 100$, was 1.73\% (standard deviation 2.28) in Vatnshlíđarvatn, and $1.60 \%$ (standard deviation 2.23) in Thingvallavatn. As an independent performance measure, we calculated condition factor as residuals of a regression of total body mass on fork length within each morph (Jakob et al., 1996).

This article is protected by copyright. All rights reserved. 
We used estimates of recent growth and condition factor to estimate effects of shape on fitness. Due to difficulties assessing fitness directly in aquatic populations, we use performance measures related to our focal traits and trophic performance, and which we expect to affect fitness. Although there are exceptions, generally growth rate and condition factor have positive effects on fitness in fish through survival, mating success and fecundity (e.g. Dickerson et al. 2002; Foote 1990; Morita \& Takashima 1998; Wootton 1973; Bolnick \& Araújo 2011). Because we lack estimates of growthfitness or condition factor-fitness relationships in our study populations, our estimates are performance gradients (Arnold, 1983) and cannot be interpreted quantitatively as selection gradients. However, under the assumption that these relationships are monotonic, performance gradients should reflect qualitative features of the true selective surface (Franklin \& Morrissey 2017).

Our proxies of trophic resource use are stable isotopic signatures of $\delta 13 \mathrm{C}$ and $\delta 15 \mathrm{~N}$, and counts of Diphyllobothrium and Diplostomum parasite infections. Benthic primary producers integrate less $12 \mathrm{C}$ (greater $\delta 13 \mathrm{C}$ ) than pelagic producers due to less turbulence in benthic boundary layers (Hecky \& Hesslein, 1995), and $15 \mathrm{~N}$ is enriched (greater $\delta 15 \mathrm{~N}$ ) with each additional trophic level (Minagawa \& Wada, 1984). Together, $\delta 13 \mathrm{C}$ and $\delta 15 \mathrm{~N}$ provide estimates of time-integrated use of trophic resources (e.g. Knudsen et al., 2014; Berchtold et al., 2015). In Thingvallavatn, lower $\delta 13 \mathrm{C}$ values associate with consumption of Copepoda and greater $\delta 13 \mathrm{C}$ values associate with Lymnaea, while Cladocera and Chironomidae exhibit intermediate values. Planktivore and small benthic charr exhibit variation in $\delta 13 \mathrm{C}$ corresponding to planktivorous and benthic diet expectations, with a degree of overlap potentially due to use of larval (small benthic) or emerging (planktivore) Chironomidae (Malmquist et al., 1992; Franklin, 2017). In Vatnshlíđarvatn, greater $\delta 13 C$ associates with increased resource breadth (more taxa identified in gut contents), and morphs differ in $\delta 13 \mathrm{C}$ values consistent with specialist and generalist diets (Franklin, 2017). In addition to quantifying resource use over several months using $\delta 13 \mathrm{C}$ and $\delta 15 \mathrm{~N}$ (Guelinckx et al., 2007), counts of trophically-transmitted parasites are a proxy for cumulative consumption of Copepoda and Lymnaea (Bérubé \& Curtis, 1986;

This article is protected by copyright. All rights reserved. 
Wilson et al., 2002; Voutilainen et al., 2008; Henriksen et al., 2015). Diphyllobothrium intensity increases with cumulative consumption of Copepoda, and is greater in the planktivore charr of Thingvallavatn and the silver charr of Vatnshlíđarvatn, whereas intensity of Diplostomum, transmitted via the water column from Lymnaea hosts, is greater in small benthic and brown charr (Franklin, 2017), controlling for size in both cases. Although Diplostomum can cause cataracts, and Diphyllobothrium become encysted in the body cavity (Bérubé \& Curtis, 1986; Voutilainen et al., 2008), the greater parasite intensities observed in larger fish, including within cohorts (Franklin, 2017), suggests that energetic benefits of resource consumption may generally outweigh detrimental effects of parasitism.

\section{Performance-based inference of selection}

We estimated directional and quadratic performance gradients (Arnold 1983) using lakewidestandardised (across morph) data to assess indications of diversifying selection independent of morph designations. Within each lake our performance measure of growth was relativised by dividing by mean growth across morphs and regressed on z-standardised shape traits (RW1 to RW5 and relative pectoral fin length), including covariates of age, sex, residual gonad mass, and fork length; residual gonad mass are estimates of gonadal investment calculated as residuals of regressions of gonad mass on total body mass. Positive quadratic coefficients along with identification of a growth minimum within the range of phenotypes are indicative of diversifying selection. We then used a path analytical approach, using within-morph data throughout, to explore functional relationships among shape, resource use, and relative growth. The total effects of shape on relative growth can be considered 'extended performance gradients' in the manner of extended selection gradients ( $\eta$; Morrissey, 2014). These total effects are the sum of all effects of shape on growth, via measured or unmeasured pathways, and can qualitatively reflect selection for shape (Franklin \& Morrissey, 2017). Total effects can be divided into indirect and direct effects on growth: 
indirect effects involve mediating variables determined by functional hypotheses (here, trophic proxies of isotopic signatures and parasite infections; Fig. 1a); direct effects are any effects for which intermediate variables are not included (Shipley, 2000). This partitioning allows us to identify the presence of diversifying selection (total effects), and determine if shape's effects are via trophic performance, parasitism, or unmeasured non-trophic functions.

Our path model (Fig. 1a) relating traits to growth presents a hypothesis whereby relative growth is affected by shape traits and resource use, represented by parasite infections over the long term and stable isotopic signatures over several months. Parasite infections are affected by shape traits and stable isotopic signatures. Stable isotopic signatures are affected by shape traits. Relative growth is individual growth divided by mean growth within morph, parasite infections are log counts, shape variables are relative warps 1 through 5 and residuals of pectoral fin length regressed on fork length. In addition, each path includes covariates of fork length ( $\mathrm{mm}$ ), sex (binary), residual gonad mass, and age (continuous covariate). The path-model equations are detailed in the appendix. Although effects on growth rate might vary inter-annually, we assume cumulative growth over several years is positively associated with fitness, allowing us to pool sampling years and improve statistical power. We log-transformed parasite data prior to inclusion in the path model, ensuring that there were minimal (and no qualitative) differences between the log-transformed models and log-link negative binomial models. We then z-standardised all variables except relative growth, and used the lavaan package in R (Rosseel, 2012) to carry out path analyses with bootstrapped standard errors on the data as provided. We repeated path analyses using condition factor as an independent response variable. We refer to our trophic pathways as capturing effects via differential prey resource use, yet there is invariably trophic variation that we cannot include such as physiological variation (Afik \& Karasov, 1995; Pörtner et al., 2013), or variation within isotopic signatures (e.g. different-sized prey may not differ in isotopic signature, but may differ in profitability). Despite these limitations, we 
expect to observe effects of shape on growth via our trophic pathways, as implied by prior research suggesting adaptation to differential use of prey taxa (e.g. Malmquist et al. 1992; Jónsson \& Skúlason 2000). Having estimated path coefficients, we compared coefficients between coexisting morphs using two-sample $z$-tests, $z=y_{a}-y_{b} / V\left(s_{a}{ }^{2}+s_{b}{ }^{2}\right)$, where $y$ is the path coefficient, se is the associated standard error, and subscripts denote compared morphs.

\section{Size-dependent mortality}

To address a component of the growth-fitness relationship we explored size-dependent mortality within morphs by comparing frequency distributions of backcalculated length at a given age for fish caught in 2014 to those caught in 2016. The 2014 sample of a particular cohort represents an initial population, while the 2016 sample of the same cohort represents the subset of the population that survived a two-year selective period. A systematic difference in mean length (measured at a common age) suggests size-dependent mortality: if selection were for larger individuals, as is generally expected in fishes (e.g. Sogard, 1997; Morita \& Takashima, 1998), the 2016 sample of fish would have a greater mean back-calculated length at the given age. This approach allowed us to account for inter-annual variation in size-dependent mortality by comparing only fish from the same cohort. For example, we compared age 5+ caught fish in 2016 (after selection) with age 3+ caught fish in 2014 (before selection) with length back-calculated to age 3+ in both cases. We calculated directional selection differentials within each morph by deducting the 2014 size data from the 2016 size data, using $z$-standardised size data, and assessing deviation from zero with t-tests $(\mathrm{p}<0.05)$. Nonlinear selection differentials were calculated by deducting the variance of 2014 size data from the variance of the 2016 size data, then adding the squared value of the directional selection differential to account for reductions in variance associated with directional selection; F-tests assessed significant deviation from zero at $p<0.05$.

This article is protected by copyright. All rights reserved. 


\section{Results}

Lakewide performance gradients revealed effects of shape on growth that are consistent with diversifying selection in both lakes, but only in Thingvallavatn did they reflect morphology associated with trophic expectations. In Thingvallavatn, quadratic RW1T was positive $\left(g_{936}=0.051\right.$, se $=0.020$, $p=0.012$; Table 1) indicating intermediate shapes experiencing reduced growth relative to extremes on an axis summarising head size, mouth position, and body elongation. In Vatnshlíđarvatn, quadratic RW1V and RW5V were negative, indicating intermediates experiencing increased relative growth; although RW4V was positive $\left(g_{1199}=0.040\right.$, se $=0.016, p=0.011 ;$ Table 1$)$, this reflects an aspect of shape for which no a priori expectations exist. These nonlinear effects, including whether they are mediated by trophic resource use, were further investigated by exploring within-morph patterns in path analyses.

\section{(a) Total effects of shape on growth}

Shape affects growth in opposing directions between coexisting morphs in Thingvallavatn but not in Vatnshlíđarvatn. In Thingvallavatn, consistent with expectations, RW1T has a positive total effect on growth in planktivore charr $\left(b_{305}=0.039, s e=0.020, p=0.046\right)$ but a negative total effect in small benthic charr $\left(b_{269}=-0.047\right.$, se $=0.024, p=0.051$; Table 2 details effects of RW1T and RW2T, see Tables S2 and S3 for further shape variables). These morph estimates differ significantly from each other ( $p=0.006$, z-test, Table 2). Because RW1T involves variation in head size, mouth position, and elongation of the caudal region, these results support a priori predictions of diversifying selection for shape. Additionally, a negative effect of RW2T on growth detected in small benthic charr was absent in planktivore charr, representing an effect of mid-body depth differing significantly between morphs ( $p=0.007$, $z$-test, Table 2). In Vatnshlíđarvatn, RW1V had positive effects on growth in both morphs while RW2V has negative effects significant only in silver charr (Table 3; Tables S4 and S5 for further shape variables). Brown and silver charr do not differ in total effects on growth for any shape variables ( $p>0.05$, z-tests, Table S6). Rather, relatively larger heads (RW1V) and shallower bodies

This article is protected by copyright. All rights reserved. 
(RW2V) associate with increased growth in both morphs. These total effects allow inferences regarding the form of selection. To explore function, we examined relationships among trophic resources and growth.

\section{(b) Effects of trophic resource use on growth}

Trophic resource use appears to affect growth only in planktivore and silver charr, largely due to detrimental effects of parasitism. No resource proxies significantly associated with growth for small benthic charr, though $\delta 13 \mathrm{C}$ and $\delta 15 \mathrm{~N}$ positively associate with Diplostomum infections (Table 2a). For planktivore charr, isotopic signatures associate with growth only through Diphyllobothrium and Diplostomum infections, which have negative effects (Table 2a, Fig. 1b). In Vatnshlíđarvatn, though trophic resource proxies had no significant associations with each other or with growth for brown charr, $\delta 13 \mathrm{C}$ did have a marginally non-significant $(\mathrm{p}=0.08)$ negative effect on growth (Table $3 a)$. A significant negative effect of $\delta 13 \mathrm{C}$ on growth was identified in silver charr, in addition to increasing Diplostomum infections which further negatively affected growth (Table 3a).

\section{(c) Effects of shape on growth via trophic resources}

Although shape affected growth via trophic resources in planktivore and silver charr, the mechanism is not consistent with expectations of trade-offs influencing trophic performance. For planktivore charr, greater RW1T increased growth by increasing $\delta 13 \mathrm{C}$, which reduced detrimental

Diphyllobothrium infections (Fig. 1b, Table 2). Although covariance of shape and growth is as predicted, the details differ: more streamlined individuals with terminal mouths (positive RW1T) have increased growth because they consume fewer Copepoda (increased $\delta 13 \mathrm{C}$ ) and experience lower copepod-transmitted parasite infections. Other aspects of shape that affect planktivore charr growth via trophic pathways, RW2T and RW3T, follow the same pattern (Table 2, Table S3). In silver

This article is protected by copyright. All rights reserved. 
charr RW3V and RW4V affect growth by increasing $\delta 13 \mathrm{C}$ and Diplostomum infections, respectively $(p<0.05 ;$ Table S5 a-c). However, these aspects of shape did not have a significant total effect on growth, suggesting opposing effects via non-trophic pathways. In small benthic and brown charr, trophic resources did not associate with growth, and so there were no effects of shape on growth via trophic pathways. There were however associations suggesting shape-dependent resource-use: greater RW3T increased Diplostomum infection, and RW4T and pectoral fin length influenced isotopic signature in small benthic charr (Table S3a), while for brown charr greater RW1V increased Diplostomum infection (Table 3). The lack of effects on growth via trophic resources and the presence of total effects of shape suggest non-trophic effects of shape for these morphs also.

\section{Direct effects of shape on growth}

Effects of shape on growth independent of trophic resource pathways are large compared with effects via trophic pathways. The total effects of RW1T and RW2T on growth in small benthic charr that oppose those in planktivore charr are largely due to differing direct effects (RW1T $p=0.022$, RW2T $p=0.001$, z-test, Table 2), rather than effects via trophic pathways. The magnitude of direct effects in both Vatnshlíđarvatn morphs are considerably larger than effects via trophic pathways, and do not differ between morphs (Table 3, Tables S4 and S5). In addition, effects of shape via trophic pathways in planktivore and silver charr are often opposed by direct effects, nullifying their net influence on growth (e.g. planktivore RW2T, Table 2a and c; silver RW3V and RW4V, Table S5a and c). The associations between shape and growth that could not be explained by trophic resource pathways suggest that non-trophic functions of shape may play an important selective role.

Repeating path analyses with condition factor as a response revealed no qualitative differences via trophic pathways to those presented above. Although direct effects of shape on condition differed to the equivalent effects on growth, due to covariance of deeper bodies with greater condition factor, condition factor revealed no additional opposing effects among morphs (data not shown).

This article is protected by copyright. All rights reserved. 


\section{Size-dependent mortality}

Differences in size-dependent mortality between coexisting morphs were evident in both lakes. Small benthic charr experienced selection for smaller sizes between 2014 and 2016, significant in age comparisons of 2 to 4 (before selection: $101 \mathrm{~mm}$, after: $89 \mathrm{~mm}, \mathrm{~S}=-0.607$, se $=0.134, \mathrm{t}_{83}=-3.78$; Table 4) and 3 to 5 (before: $121 \mathrm{~mm}$, after: $109 \mathrm{~mm}, \mathrm{~S}=-0.474$, se=0.125, $\mathrm{t}_{81}=-3.13$ ), whereas planktivore charr experienced selection for larger sizes over the same period, significant in age comparisons of 4 to 6 (before: $135 \mathrm{~mm}$, after: $152 \mathrm{~mm}, \mathrm{~S}=0.323$, se $=0.072, \mathrm{t}_{379}=3.47$ ) and 5 to 7 (before: $161 \mathrm{~mm}$, after: $181 \mathrm{~mm}, \mathrm{~S}=-0.540$, se=0.098, $\mathrm{t}_{165}=4.59$ ). Although we obtained no statistically significant selection differentials in other age classes, effect sizes suggest it is advantageous for small benthic charr to be smaller at times when larger planktivore charr are advantaged. In Vatnshlíđarvatn, silver charr experienced selection of larger sizes in all age-classes, whereas there was no size selection in brown charr that significantly differed from zero, though estimates were positive (Table 4). There were no significant estimates of nonlinear size-dependent mortality in any morph (data not shown).

\section{Discussion}

Complex relationships among various ecological factors promote morphological diversity even in relatively simple and young polymorphic systems, as demonstrated through our novel use of the extended selection gradient path analytical approach. Contrary to general expectations (e.g. Malmquist et al., 1992; Robinson \& Wilson, 1994; Arnegard et al., 2014), morphological trade-offs contributed little to diversifying selection via effects on trophic performance. In Thingvallavatn, the lake with greater phenotypic differentiation, morphologically intermediate individuals experienced reduced relative growth, indicating disruptive selection of shape if growth is monotonically related to fitness (Franklin \& Morrissey, 2017). This diversifying selection is mediated by detrimental effects of Diphyllobothrium (Copepoda-transmitted tapeworms) and effects of shape on growth independent of resource use variation. In Vatnshlíđarvatn we found no support for diversifying

This article is protected by copyright. All rights reserved. 
selection and shape predominantly affected growth independent of resource use. Our observations of parasite-mediated diversifying selection, non-trophic effects of shape, and contrasting patterns of size-dependent mortality between morphs, suggest a limited role for morphological-trade offs influencing fitness via trophic performance under natural conditions.

\section{Effects via trophic resource use}

Effects of shape on growth via trophic resource use are mediated by parasitism and suggest alterative functional explanations to that of prey capture efficiency. In Thingvallavatn, streamlinedbodied planktivore charr (increased RW1T) experience greater growth by consuming fewer Copepoda (greater $\delta 13 C$ ), thus experiencing lower Diphyllobothrium infections. This may reduce subsequent internal haemorrhaging (Bérubé \& Curtis, 1986). The shape-dependent use of Copepoda, and subsequent parasite exposure, appears not to result from biomechanical limitations involving prey capture: Thingvallavatn planktivore charr frequently consume Daphnia which are less parasitised and more easily captured than Copepoda (Malmquist, 1992; Malmquist et al., 1992; Franklin, 2017). Alternative explanations for shape-depedndent resource use may involve hydrodynamic demands associated with behaviours such as increased search behaviours, and/or boldness in foraging farther from the shoal (Ehlinger, 1990; Mikheev et al., 1996; Adams, 2004; Edelsparre et al., 2013). Shape-dependent parasitism was also evident in small benthic and brown charr, but without subsequent effects on growth. Variation in parasitism may result from differential use of the spatial environment, as suggested by the prevalent Diplostomum infections of brown charr despite rare consumption of Lymnaea (Jónsson \& Skúlason, 2000; Franklin, 2017).

Where resource use variation did affect growth independent of parasitism, it did not contribute to diversifying selection. In Vatnshlíđarvatn consumption of fewer taxa associated with greater growth, contrary to expectations for the generalist silver charr (Jónsson \& Skúlason, 2000). In addition, shape did not influence variation in resource breadth as would be necessary to support a morphological

This article is protected by copyright. All rights reserved. 
trade-off hypothesis between the specialist and generalist morphs. Therefore, morphological tradeoffs do not contribute to Vatnshlíđarvatn diversification via resource use under contemporary conditions, notwithstanding fluctuations over timescales greater than our three-year study (e.g. Wilson \& Yoshimura, 1994).

Non-trophic effects

Shape affected growth independent of resource use variation, and we suggest this arises in part from biomechanical constraints of swimming behaviours associated with predator avoidance and escape (Webb, 1975; Bolnick \& Araújo, 2011; Ellerby \& Gerry, 2011; Samways et al., 2015). Interindividual variation in predator-avoidance behaviour often associates with morphology (Mikheev et al., 1996; Hawley et al., 2016), and in Thingvallavatn behavioural differences are evident. Planktivore charr exhibit shoaling, reluctance to forage without conspecifics, and spend considerable time hovering in the water column. Small benthic charr travel independently, are often stationary on the substrate and utilise refuges within the complex lava substrate (Malmquist, 1992; Sandlund et al., 1992; Skúlason et al., 1993; Kristjánsson et al., 2011). Such behavioural variation could result in diversifying selection of shape via energetic costs of locomotion, independent of trophic resource use.

Predation may play a role in polymorphism in Thingvallavatn and Vatnshlíđarvatn through sizeselective mortality and behavioural responses. Predation as a cause of divergence has received considerable support (Rundle et al., 2003; Langerhans \& Reznick, 2009; Scharnweber et al., 2013) and our selection differentials indicate that size-dependent mortality differs in direction (Thingvallavatn) or magnitude (Vatnshlíđarvatn) between coexisting morphs. Predation on intermediate-sized fish could act as a diversifying mechanism and could promote diversification in charr behavioural responses (Doucette et al. 2004; Parsons, 2008). Subsequent contrasting locomotive costs, prey and parasite exposure, or spawning behaviour, could have morphological

This article is protected by copyright. All rights reserved. 
implications (Reznick, 1983; Stearns, 1989; Hutchings, 1993). In both lakes, differences between coexisting morphs in behaviour associated with predation (Malmquist, 1992; Skúlason et al., 1993; Parsons, 2008), in growth rate and life history (Sandlund et al., 1992; Jónsson \& Skúlason, 2000), and our data suggesting non-trophic costs of shape and size-dependent mortality, may together suggest a diversifying role for predation.

\section{Implications}

We found little support for morphological trade-offs contributing to polymorphism through trophic performance under contemporary conditions. However, colonising charr 10,000 years ago experienced different conditions to today's populations, and a complex of interacting ecological factors may have contributed to initiation and maintenance of polymorphism. Whether or not biomechanical constraints influencing trophic performance were an initial cause of morphological polymorphism, this study has demonstrated that resource polymorphisms can persist in its absence, despite potential gene flow.

Our sampling approach allowed us to make inferences regarding selection via trophic resources, but naturally there were limitations. In Thingvallavatn it is possible that morph subpopulations exist, which might vary in phenotype, resource availability, and gene flow (Sandlund et al., 1992; Kapralova et al., 2011). We sampled in the littoral zone, obtaining planktivore charr that were likely more similar ecologically to small benthic charr compared with those in pelagic zones. This allowed us to examine selective processes where overlap in phenotype and resource use was most likely, and therefore to speculate on the fitness of potential inter-morph hybrids. During sampling we were also unable to sample the youngest cohorts adequately and may have overlooked selection via trophic pathways in young of the year. Although we expect competition in early life stages to be strong (Perez \& Munch, 2010), reduced variation in morphology and feeding performance early in ontogeny (Skúlason et al., 1989b; Parsons, 2008) and limited juvenile diet breadth (Sandlund et al., 1988)

This article is protected by copyright. All rights reserved. 
suggest that selection likely results from interference competition and variation in size rather than shape. However, as suggested by differences in size among morphs, competition in the nursery grounds might contribute to morph formation if size thresholds trigger faster growing individuals to switch to pelagic environments with different ecological conditions (Byström et al., 2014).

We estimated performance gradients, which are qualitatively indicative of selection gradients when growth and fitness are monotonically related in the wild (Arnold, 1983; Franklin \& Morrissey, 2017). Although the general expectation for fish is that increased growth results in greater fitness, this is not always the case (Dickerson et al., 2002; Foote, 1990; Morita \& Takashima, 1998; Barber et al., 2001; Carlson et al., 2008), and our data indicate that increased size can reduce survival of small benthic charr. Furthermore, differences in age at maturity and asymptotic size between coexisting morphs in both Thingvallavatn and Vatnshlíđarvatn (Jonsson et al. 1988; Skúlason et al., 1996; Jónsson \& Skúlason, 2000) are suggestive of fitness component trade-offs resulting from different growth-fitness relationships between morphs (Reznick, 1983; Stearns, 1989; Hutchings, 1993). The potential for non-monotonic growth-fitness relationships may have implications for the forms of selection experienced in these systems, though this would not invalidate our observations regarding the roles of morphology via trophic performance. Measurement of growth-fitness relationships in the wild remains necessary to quantify fitness effects of parasitism and morphology via non-trophic functions.

In conclusion, this study demonstrates that phenotype contributes to performance via multiple functions and that consideration of a complex of local ecological factors is necessary to understand diversification. We identified parasitism, non-trophic effects of shape, and size as factors likely influencing fitness in resource polymorphisms, with indications of disruptive selection of shape in Thingvallavatn and differing size-dependent mortality between morphs in both lakes. Because alternative functions can produce similar trait-performance covariance patterns, we stress the importance of measuring the nature of selection in the wild. Our observations using path analyses

This article is protected by copyright. All rights reserved. 
and individual-level data revealed effects of shape inconsistent with assumptions based on intuitive morph categories. Phenotypic trade-offs influencing trophic performance have been identified or assumed in numerous systems (e.g. Price, 1987; Schluter, 1995), yet there remain few studies of diversifying selection in the wild, within few focal systems (Kingsolver et al., 2001; Siepielski et al., 2013). This study therefore represents a valuable contribution to understanding early diversification in nature. Finally, if morphological trade-offs do not influence trophic performance under contemporary conditions, this suggests either that in these relatively simple and young systems, processes contributing to initial morphological diversification differ from those that now maintain them, or that such trade-offs did not contribute to morphological diversification. In either case, this highlights the need for a more nuanced understanding of the selective processes that result in intraspecific diversity.

\section{References}

Ackermann, M. \& Doebeli, M. 2004. Evolution of niche width and adaptive diversification. Evolution, 58: 2599-2612.

Adams, D.C. 2004. Character displacement via aggressive interference in Appalachian salamanders. Ecology, 85: 2664-2670.

Afik, D. \& Karasov, W.H. 1995. The trade-offs between digestion rate and efficiency in warblers and their ecological implications. Ecology, 76: 2247-2257.

Arnegard, M.E., McGee, M.D., Matthews, B., Marchinko, K.B., Conte, G.L., Kabir, S., et al. 2014. Genetics of ecological divergence during speciation. Nature, 511: 307-311.

Arnold, S.J. 1983. Morphology, performance and fitness. Am. Zool., 23: 347-361.

Barber, I., Arnott, S.A., Braithwaite, V.A., Andrew, J. \& Huntingford, F.A. 2001. Indirect fitness consequences of mate choice in sticklebacks: offspring of brighter males grow slowly but resist parasitic infections. Proc. R. Soc. Lond. B, 268: 7176

Berchtold, A.E., Colborne, S.., F.J, L. \& Neff, B.D. 2015. Ecomorphological patterns linking morphology and diet across three populations of pumpkinseed sunfish (Lepomis gibbosus). Can. J. Zool., 93: 289-297.

This article is protected by copyright. All rights reserved. 
Bérubé, M. \& Curtis, M.A. 1986. Transmission of Diphyllobothrium ditremum to Arctic char (Salvelinus alpinus) in two subarctic Quebec lakes. Can. J. Fish. Aquat. Sci., 43: 1626-1634.

Bolnick, D.I. \& Araújo, M.S. 2011. Partitioning the relative fitness effects of diet and trophic morphology in the threespine stickleback. Evol. Ecol. Res., 13: 439-459.

Bolnick, D.I., Svanbäck, R., Fordyce, J.A., Yang, L.H., Davis, J.M., Hulsey, C.D., et al. 2003. The ecology of individuals: incidence and implications of individual specialization. Am. Nat., 161: 1-28.

Byström, P., Andersson, J., Persson, L. \& Roos, A.M. De. 2014. Size-dependent resource limitation and foraging-predation risk trade-offs: growth and habitat use in young Arctic char. Oikos, 104: 109-121.

Campana, S.E. 1990. How reliable are growth back-calculations based on otoliths? Can. J. Fish. Aquat. Sci., 47: 2219-2227.

Campana, S.E. \& Jones, C.M. 1992. Analysis of Otolith Microstructure Data. In: Otolith microstructure examination and analysis (D. K. Stevenson \& S. Campana, eds), pp. 73-100. Canadian Special Publication of Fisheries and Aquatic Sciences.

Carlson, S.M., Olsen, E.M. \& Vøllestad, L.A. 2008. Seasonal mortality and the effect of body size: a review and an empirical test using individual data on brown trout. Funct. Ecol., 22: 663-673.

Casselman, J.M. 1990. Growth and relative size of calcified structures of fish. Trans. Am. Fish. Soc., 8487: 37-41.

Dickerson, B.R., Quinn, T.P. \& Willson, M.F. 2002. Body size, arrival date, and reproductive success of pink salmon, Oncorhynchus gorbuscha. Ethol. Ecol. Evol., 14: 29-44.

Doucette, L.I., Skúlason, S., \& Snorrason, S.S. 2004. Risk of predation as a promoting factor of species divergence in threespine sticklebacks (Gasterosteus aculeatus L.). Biol. J. Linn. Soc., 82: 189203.

Edelsparre, A.H., McLaughlin, R.L. \& Rodríguez, M. a. 2013. Risk taking not foraging behavior predicts dispersal of recently emerged stream brook charr (Salvelinus fontinalis). Ecosphere, 4: 73.

Ehlinger, T.J. 1990. Habitat choice and phenotype-limited feeding efficiency in bluegill: individual differences and trophic polymorphism. Ecology, 71: 886-896.

Ellerby, D.J. \& Gerry, S.P. 2011. Sympatric divergence and performance trade-offs of bluegill ecomorphs. Evol. Biol., 38: 422-433.

Foote, C.J. 1990. An experimental comparison of male and female spawning territoriality in a Pacific Salmon. Behaviour, 106: 63-80.

Franklin, O.D. 2017. Phenotypic selection of morphology in polymorphic Arctic charr (Salvelinus alpinus). PhD thesis. University of Guelph.

Franklin, O.D. \& Morrissey, M.B. 2017. Inference of selection gradients using performance measures as fitness proxies. Methods Ecol. Evol., 8: 663-677.

This article is protected by copyright. All rights reserved. 
Geirsdóttir, A., Miller, G.H., Axford, Y. \& Ólafsdóttir, S. 2009. Holocene and latest Pleistocene climate and glacier fluctuations in Iceland. Quat. Sci. Rev., 28: 2107-2118.

Ghalambor, C.K., Walker, J.A. \& Reznick, D.N. 2003. Multi-trait selection, adaptation, and constraints on the evolution of burst swimming performance. Integr. Comp. Biol., 43: 431-438.

Gíslason, D., Ferguson, M.M., Skúlason, S. \& Snorrason, S.S. 1999. Rapid and coupled phenotypic and genetic divergence in Icelandic Arctic char (Salvelinus alpinus). Can. J. Fish. Aquat. Sci., 56: 2229-2234.

Guelinckx, J., Maes, J., Van Den Driessche, P., Geysen, B., Dehairs, F. \& Ollevier, F. 2007. Changes in $\delta 13 \mathrm{C}$ and $\delta 15 \mathrm{~N}$ in different tissues of juvenile sand goby Pomatoschistus minutus: a laboratory diet-switch experiment. Mar. Ecol. Prog. Ser., 341: 205-215.

Hawley, K.L., Rosten, C.M., Christensen, G. \& Lucas, M.C. 2016. Fine-scale behavioural differences distinguish resource use by ecomorphs in a closed ecosystem. Sci. Rep., 6: 24369.

Hecky, R.E. \& Hesslein, R.H. 1995. Contributions of benthic algae to lake food webs as revealed by stable isotope analysis. J. North Am. Benthol. Soc., 14: 631-653.

Henriksen, E.H., Knudsen, R., Kristoffersen, R., Kuris, A.M., Lafferty, K.D., Siwertsson, A., et al. 2015. Ontogenetic dynamics of infection with Diphyllobothrium spp. cestodes in sympatric Arctic charr Salvelinus alpinus (L.) and brown trout Salmo trutta L. Hydrobiologia, 783: 37-46.

Herrel, A., O'Reilly, J.C. \& Richmond, A.M. 2002. Evolution of bite performance in turtles. J. Evol. Biol., 15: 1083-1094.

Herrel, A., Podos, J., Vanhooydonck, B., \& Hendry, A.P. 2009. Force-velocity trade-off in Darwin's finch jaw function: a biomechanical basis for ecological speciation? Functional Ecology, 23: 119-125.

Herron, M.D. \& Doebeli, M. 2013. Parallel evolutionary dynamics of adaptive diversification in Escherichia coli. PLoS Biol., 11: e1001490.

Hutchings, J. 1993. Adaptive life histories effected by age-specific survival and growth rate. Ecology, 74: 673-684.

Jakob, E.M., Marshall, S.D., \& Uetz, G.W. 1996. Estimating fitness: a comparison of body condition indices. Oikos, 77: 61-67.

Jónasson, P.M. 1992. The ecosystem of Thingvallavatn: a synthesis. Oikos, 64: 405-434. Odense, Denmark: AiO Print.

Jónsson, B. \& Skúlason, S. 2000. Polymorphic segregation in Arctic charr Salvelinus alpinus (L.) from Vatnshlíđarvatn, a shallow Icelandic lake. Biol. J. Linn. Soc., 69: 55-74.

Jonsson, B., Skúlason, S., Snorrason, S.S., Sandlund, O.T., Malmquist, H.J., Jónasson, P.M., et al. 1988. Life history variation of polymorphic Arctic charr (Salvelinus alpinus) in Thingvallavatn, Iceland. Can. J. Fish. Aquat. Sci., 45: 1537-1547.

This article is protected by copyright. All rights reserved. 
Kapralova, K.H., Morrissey, M.B., Kristjánsson, B.K., Olafsdóttir, G.Á., Snorrason, S.S. \& Ferguson, M.M. 2011. Evolution of adaptive diversity and genetic connectivity in Arctic charr (Salvelinus alpinus) in Iceland. Heredity, 106: 472-87.

Karvonen, A., \& Seehausen, O. 2012. The role of parasitism in adaptive radiations-when might parasites promote and when might they constrain ecological speciation? International Journal of Ecology, 2012: 1-20.

Karvonen, A., Seppälä, O. \& Valtonen, E.T. 2004. Parasite resistance and avoidance behaviour in preventing eye fluke infections in fish. Parasitology, 129: 159-164.

Keast, A. \& Webb, D. 1966. Mouth and body form relative to feeding ecology in the fish fauna of a small lake, Lake Opinicon, Ontario. J. Fish. Res. Board Canada, 23: 1845-1874.

Kingsolver, J.G., Hoekstra, H.E., Hoekstra, J.M., Berrigan, D., Vignieri, S.N., Hill, C.E., et al. 2001. The strength of phenotypic selection in natural populations. Am. Nat., 157: 245-261.

Klemetsen, A. 2010. The charr problem revisited: exceptional phenotypic plasticity promotes ecological speciation in postglacial lakes. Freshw. Rev., 3: 49-74.

Knudsen, R., Siwertsson, A., Adams, C.E., Newton, J. \& Amundsen, P.-A. 2014. Similar patterns of individual niche use are revealed by different time-integrated trophic tracers (stable isotopes and parasites). Ecol. Freshw. Fish, 23: 259-268.

Kristjánsson, B.K., Malmquist, H.J., Ingimarsson, F., Antonsson, T., Snorrason, S.S. \& Skúlason, S. 2011. Relationships between lake ecology and morphological characters in Icelandic Arctic charr, Salvelinus alpinus. Biol. J. Linn. Soc., 103: 761-771.

Langerhans, R.B. \& Reznick, D.N. 2009. Ecology and evolution of swimming performance in fishes: predicting evolution with biomechanics. In: Fish locomotion: An eco-ethological perspective (P. Domenici \& B. G. Kapoor, eds), pp. 200-248. Enfield, New Hampshire: Science Publishers.

Malmquist, H.J. 1992. Phenotype-specific feeding behaviour of two arctic charr Salvelinus alpinus morphs. Oecologia, 92: 354-361.

Malmquist, H.J., Snorrason, S.S., Skúlason, S., Jónsson, B., Sandlund, O.T. \& Jónasson, P.M. 1992. Diet differentiation in polymorphic Arctic charr in Thingvallavatn, Iceland. J. Anim. Ecol., 61: 2135.

Martin, R.A., \& Pfennig, D.W. 2010. Field and experimental evidence that competition and ecological opportunity promote resource polymorphism. Biol. J. Linn. Soc., 100: 73-88.

Mikheev, V.N., Adams, C.E., Huntingford, F.A. \& Thorpe, J.E. 1996. Behavioural responses of benthic and pelagic Arctic charr to substratum heterogeneity. J. Fish Biol., 49: 494-500.

Minagawa, M. \& Wada, E. 1984. Stepwise enrichment of 15N along food chains: Further evidence and the relation between d15N and animal age. Geochim. Cosmochim. Acta, 48: 1135-1140.

Mitchell-Olds, T. \& Shaw, R. 1987. Regression analysis of natural selection: statistical inference and biological interpretation. Evolution, 41: 1149-1161.

This article is protected by copyright. All rights reserved. 
Morita, K. \& Takashima, Y. 1998. Effect of female size on fecundity and egg size in white-spotted charr: comparison between sea-run and resident forms. J. Fish Biol., 53: 1140-1142.

Morrissey, M.B. 2014. Selection and evolution of causally covarying traits. Evolution, 68: 1748-61.

Morrissey, M.B., Kruuk, L.E.B., \& Wilson, A.J. 2010. The danger of applying the breeder's equation in studies of natural populations. J. Evol. Biol. 23: 2277-88.

Norddahl, H. \& Einarsson, T. 2001. Concurrent changes of relative sea-level and glacier extent at the Weichselian-Holocene boundary in Berufjordur, Eastern Iceland. Quat. Sci. Rev., 20: 16071622.

Nosil, P. 2012. Ecological speciation. Oxford: Oxford University Press.

Parsons, K.J. 2008. Phenotypic plasticity and the genetic basis of adaptive divergence in Icelandic Arctic charr (Salvelinus alpinus). PhD thesis. University of Guelph.

Perez, K.O. \& Munch, S.B. 2010. Extreme selection on size in the early lives of fish. Evolution, 64: 2450-7.

Pörtner, H.O., Schulte, P.M., Wood, C.M. \& Schiemer, F. 2013. Niche dimensions in fishes: an integrative view. Physiol. Biochem. Zool., 83: 808-26.

Price, T. 1987. Diet variation in a population of Darwin's finches. Ecology, 68: 1015-1028.

Radtke, R.L., Fey, D.P., Decicco, A.F. \& Montgomery, A. 1996. Otolith microstructure in young-of-theyear Dolly Varden, Salvelinus malma, from American and Asian populations: resolution of comparative life history characteristics. Arctic, 49: 162-169.

Reznick, D. 1983. The Structure of Guppy Life Histories: The tradeoff between growth and reproduction. Ecology, 64: 862-873.

Robinson, B.W. \& Wilson, D.S. 1994. Character release and displacement in fishes: a neglected literature. Am. Nat. 144.4: 596-627.

Rosseel, Y. 2012. lavaan: an R package for structural equation modeling. J. Stat. Softw., 48: 1-36.

Rundle, H.D., Vamosi, S.M. \& Schluter, D. 2003. Experimental test of predation's effect on divergent selection during character displacement in sticklebacks. Proc. Natl. Acad. Sci., 100: 1494314948.

Samways, K.M., Leavitt, P.R., Magnan, P., Rodríguez, M.A. \& Peres-Neto, P.R. 2015. Convergent polymorphism between stream and lake habitats: the case of brook charr. Can. J. Fish. Aquat. Sci., 72: 1406-1414.

Sandlund, O.T., Gunnarsson, K., Jónasson, P.M., Jonsson, B., Lindem, T., Magnússon, K.P., et al. 1992. The Arctic charr Salvelinus alpinus in Thingvallavatn. Oikos, 64: 305-351.

This article is protected by copyright. All rights reserved. 
Sandlund, O.T., Malmquist, H.J., Jonsson, B., Skúlason, S., Snorrason, S.S., Jonasson, P.M., et al. 1988. Density, length distribution, and diet of age- 0 arctic charr Salvelinus alpinus in the surf zone of Thingvallavatn, Iceland. Environ. Biol. Fishes, 23: 183-195.

Scharnweber, K., Watanabe, K., Syväranta, J., Wanke, T., Monaghan, M.T. \& Mehner, T. 2013. Effects of predation pressure and resource use on morphological divergence in omnivorous prey fish. BMC Evol. Biol., 13: 132.

Schluter, D. 1995. Adaptive radiation in sticklebacks: trade-offs in feeding performance and growth. Ecology, 76: 82-90.

Schluter, D. \& Rambaut, A. 1996. Ecological speciation in postglacial fishes. Philos. Trans. R. Soc. B Biol. Sci., 351: 807-814.

Shipley, B. 2000. Cause and correlation in biology. A user's guide to path analysis, structural equations and causal inference. Cambridge: Cambridge University Press.

Siepielski, A.M., Gotanda, K.M., Morrissey, M.B., Diamond, S.E., DiBattista, J.D. and Carlson, S.M. 2013. The spatial patterns of directional phenotypic selection. Ecol. Lett., 16: 1382-92

Skúlason, S., Noakes, D.L.G. \& Snorrason, S.S. 1989a. Ontogeny of trophic morphology in four sympatric morphs of arctic charr Salvelinus alpinus in Thingvallavatn, Iceland. Biol. J. Linn. Soc., 38: 281-301.

Skúlason, S., Snorrason, S.S., Noakes, D.L.G., Ferguson, M.M. \& Malmquist, H.J. 1989b. Segregation in spawning and early life history among polymorphic Arctic charr, Salvelinus alpinus, in Thingvallavatn, Iceland. J. Fish Biol., 35: 225-232.

Skúlason, S., Snorrason, S.S., Noakes, D.L.G. \& Ferguson, M.M. 1996. Genetic basis of life history variations among sympatric morphs of Arctic char, Salvelinus alpinus. Can. J. Fish. Aquat. Sci., 53: $1807-1813$

Skúlason, S., Snorrason, S.S., Ota, D. \& Noakes, D.L.G. 1993. Genetically based differences in foraging behaviour among sympatric morphs of arctic charr (Pisces: Salmonidae). Anim. Behav., 45: 1179-1192.

Smith, T.B. \& Skúlason, S. 1996. Evolutionary significance of resource polymorphisms in fishes, amphibians, and birds. Annu. Rev. Ecol. Syst., 27: 111-133.

Sogard, S.M. 1997. Size-selective mortality in the juvenile stage of teleost fishes: a review. Bull. Mar. Sci., 60.3: 1129-1157.

Stearns, S.C. 1989. Trade-offs in life-history evolution. Funct. Ecol., 3: 259-268.

Voutilainen, A., Figueiredo, K. \& Huuskonen, H. 2008. Effects of the eye fluke Diplostomum spathaceum on the energetics and feeding of Arctic charr Salvelinus alpinus. J. Fish Biol., 73: 2228-2237.

Wainwright, P.C. \& Richard, B.A. 1995. Predicting patterns of prey use from morphology of fishes. Environ. Biol. Fishes, 44: 97-113.

This article is protected by copyright. All rights reserved. 
Webb, P.W. 1975. Hydrodynamics and energetics of fish propulsion. Ottawa: Bulletin of the Fisheries Research Board of Canada.

Webb, P.W. 1984. Body form, locomotion and foraging in aquatic vertebrates. Am. Zool., 24: 107120.

Webb, P.W. \& Weihs, D. 1983. Fish biomechanics. New York: Praeger.

Wilson, A.J., Gislason, D., Skúlason, S., Snorrason, S.S., Adams, C.E., Alexander, G. et al. 2004. Population genetic structure of Arctic charr, Salvelinus alpinus from northwest Europe on large and small spatial scales. Mol. Ecol., 13: 1129-1142.

Wilson, D.S. \& Yoshimura, J. 1994. On the coexistence of specialists and generalists. Am. Nat., 144: 692-707.

Wilson, K., Bjørnstad, O.N., Dobson, A.P., Merler, S., Poglayen, G., Read, A.F., et al. 2002. Heterogeneities in macroparasite infections: patterns and processes. In: The ecology of wildlife diseases (P. J. Hudson et al., eds), pp. 6-44. Oxford: Oxford University Press.

Woods, P.J., Skúlason, S., Snorrason, S.S., Kristjánsson, B.K., Malmquist, H.J. \& Quinn, T.P. 2012. Intraspecific diversity in Arctic charr, Salvelinus alpinus, in Iceland: I. Detection using mixture models. Evol. Ecol. Res., 14: 973-992.

Wootton, R.J. 1973. The effect of size of food ration on egg production in the female three-spined stickleback, Gasterosteus, L. J. Fish Biol., 5: 89-96.

Yano, A., Nicol, B., Jouanno, E., Quillet, E., Fostier, A., Guyomard, R., et al. 2012. The sexually dimorphic on the $\mathrm{Y}$-chromosome gene (sdY) is a conserved male-specific $\mathrm{Y}$-chromosome sequence in many salmonids. Evol. Appl., 6: 486-96.

This article is protected by copyright. All rights reserved. 


\section{Tables and Figures}

Table 1: Standardised lakewide (across-morph) performance gradients of relativised growth regressed on variance-standardised shape traits, for Arctic charr from the Icelandic lakes

Thingvallavatn and Vatnshlídarvatn. RW refers to relative warps, Pec fins to pectoral fin length, and square terms indicate quadratic estimates, $p$ values below 0.05 are bold. Growth is relativised by dividing by mean growth across morphs within each lake, covariates included were age, sex, fork length and residual gonad mass. The presence of nonlinear effects in these lakewide comparisons suggests selection may operate in opposing directions between morphs. See Fig. S3 for wireframe depictions of RW1-5.

Thingvallavatn

Vatnshlíđarvatn

Variance-standardised traits Estimate Std. error

p. value

Estimate Std. error

p. value

\begin{tabular}{lllllll}
\hline RW1 & 0.065 & 0.017 & $\mathbf{0 . 0 0 0}$ & 0.061 & 0.021 & $\mathbf{0 . 0 0 3}$ \\
RW2 & 0.023 & 0.011 & $\mathbf{0 . 0 3 3}$ & -0.102 & 0.015 & $\mathbf{0 . 0 0 0}$ \\
RW3 & -0.008 & 0.010 & 0.457 & 0.013 & 0.012 & 0.265 \\
RW4 & -0.002 & 0.010 & 0.855 & 0.045 & 0.013 & $\mathbf{0 . 0 0 0}$ \\
RW5 & -0.046 & 0.010 & $\mathbf{0 . 0 0 0}$ & -0.006 & 0.013 & 0.653 \\
Pec fins & 0.008 & 0.014 & 0.560 & -0.042 & 0.019 & $\mathbf{0 . 0 2 8}$ \\
RW1 $^{2}$ & 0.051 & 0.020 & $\mathbf{0 . 0 1 2}$ & -0.041 & 0.020 & $\mathbf{0 . 0 3 8}$ \\
RW2 $^{2}$ & 0.009 & 0.014 & 0.509 & -0.014 & 0.020 & 0.483 \\
RW3 $^{2}$ & -0.006 & 0.014 & 0.672 & 0.010 & 0.015 & 0.495 \\
RW4 $^{2}$ & 0.003 & 0.010 & 0.800 & 0.040 & 0.016 & $\mathbf{0 . 0 1 1}$ \\
RW5 $^{2}$ & -0.008 & 0.014 & 0.567 & -0.047 & 0.015 & $\mathbf{0 . 0 0 2}$ \\
Pec fins $^{2}$ & 0.017 & 0.012 & 0.177 & 0.013 & 0.013 & 0.346
\end{tabular}

This article is protected by copyright. All rights reserved. 
Table 2: Path coefficients detailing effects of shape (RW1T and RW2T) on growth within samples of small benthic and planktivore Arctic charr morphs from the Icelandic lake Thingvallavatn, and z-tests comparing effects between morphs. Standardised path coefficients (a), compound path coefficients (b), effects via trophic proxies (c), and total effects (d) from the path diagram relating shape (Fig.2) to relative growth (Fig. 1a), with covariates of age, sex, residual gonad mass, and fork length. Coefficients are displayed (standard errors in parentheses) except z-test columns which display $p$-values. Bolded values are significant at $p=0.05$ (significant path coefficients differ from zero; z-test significance indicates morph coefficients differ). Growth was relativised by dividing by mean growth within morph. Greater $\delta 13 C$ indicates a benthic diet in Thingvallavatn, greater $\delta 15 \mathrm{~N}$ indicates higher trophic level, Diplostomum are flukes with snail intermediate hosts, Diphyllobothrium are tapeworms with copepod

intermediate hosts. $\delta 13 \mathrm{C}$ and $\delta 15 \mathrm{~N}$ are included separately in (a) for univariate coefficients. Because $\delta 13 \mathrm{C}$ and $\delta 15 \mathrm{~N}$ together produce an estimate of resource use, in compound path coefficients (b) they are not considered independently.

small benthic

planktivore

$$
\text { Diplo. } \quad \text { Diph. } \quad \text { RW1 RW2 } \quad \delta 13 \mathrm{C}
$$

Diplo.

Diph.

(a) path coefficients, detailing effect of column variable on row. Bottom row is direct effects of traits or trophic proxies on relative growth

p-values

\begin{tabular}{|c|c|c|c|c|c|c|c|c|c|c|c|c|c|c|}
\hline \multirow[t]{2}{*}{$\delta 13 \mathrm{C}$} & -0.106 & -0.108 & & & & & 0.148 & -0.150 & & & & & 0.015 & 0.650 \\
\hline & $(0.078)$ & $(0.064)$ & & & & & $(0.069)$ & $(0.067)$ & & & & & & \\
\hline \multirow[t]{2}{*}{$\delta 15 \mathrm{~N}$} & 0.021 & -0.029 & & & & & -0.139 & 0.211 & & & & & 0.121 & 0.009 \\
\hline & $(0.073)$ & (0.059) & & & & & $(0.073)$ & $(0.070)$ & & & & & & \\
\hline \multirow[t]{2}{*}{ Diplostomum } & 0.115 & -0.056 & 0.260 & 0.130 & & & -0.019 & 0.027 & 0.355 & 0.045 & & & 0.097 & 0.245 \\
\hline & $(0.061)$ & $(0.050)$ & $(0.047)$ & $(0.051)$ & & & $(0.053)$ & $(0.051)$ & $(0.043)$ & $(0.041)$ & & & & \\
\hline \multirow[t]{2}{*}{ Diphyllobothrium } & 0.007 & 0.008 & -0.037 & -0.058 & & & -0.056 & 0.091 & -0.322 & 0.250 & & & 0.494 & 0.287 \\
\hline & $(0.082)$ & $(0.067)$ & $(0.063)$ & $(0.068)$ & & & $(0.042)$ & $(0.040)$ & $(0.034)$ & $(0.032)$ & & & & \\
\hline \multirow[t]{2}{*}{ Relative growth } & -0.045 & -0.062 & 0.007 & 0.010 & -0.021 & 0.010 & 0.025 & 0.033 & 0.013 & 0.014 & -0.049 & -0.109 & 0.022 & 0.001 \\
\hline & $(0.024)$ & $(0.020)$ & $(0.020)$ & $(0.021)$ & $(0.024)$ & $(0.018)$ & $(0.019)$ & (0.019) & (0.019) & $(0.016)$ & $(0.021)$ & $(0.026)$ & & \\
\hline
\end{tabular}

This article is protected by copyright. All rights reserved. 
(b) compound path coefficients. Summaries of indirect effects of traits (columns) on relative growth via trophic pathways (rows)

Effect on relative growth via:

\begin{tabular}{|c|c|c|c|c|c|c|}
\hline isotopes & -0.001 & -0.001 & 0.000 & 0.001 & 0.823 & 0.710 \\
\hline & $(0.002)$ & $(0.002)$ & $(0.004)$ & $(0.005)$ & & \\
\hline \multirow[t]{2}{*}{ isotopes via Diphyllobothrium } & 0.000 & 0.000 & 0.009 & -0.011 & 0.024 & 0.006 \\
\hline & $(0.000)$ & $(0.000)$ & $(0.004)$ & $(0.004)$ & & \\
\hline \multirow[t]{2}{*}{ isotopes via Diplostomum } & 0.001 & 0.001 & -0.002 & 0.002 & 0.180 & 0.655 \\
\hline & $(0.001)$ & $(0.001)$ & $(0.002)$ & $(0.002)$ & & \\
\hline \multirow[t]{2}{*}{ Diplostomum } & -0.002 & 0.001 & 0.001 & -0.001 & 0.480 & 0.579 \\
\hline & $(0.003)$ & $(0.002)$ & $(0.003)$ & $(0.003)$ & & \\
\hline \multirow[t]{2}{*}{ Diphyllobothrium } & 0.000 & 0.000 & 0.006 & -0.010 & 0.239 & 0.050 \\
\hline & $(0.001)$ & $(0.001)$ & $(0.005)$ & $(0.005)$ & & \\
\hline \multirow[t]{2}{*}{ Relative growth } & -0.002 & 0.001 & 0.014 & -0.019 & 0.047 & 0.006 \\
\hline & $(0.004)$ & $(0.003)$ & $(0.007)$ & $(0.007)$ & & \\
\hline
\end{tabular}

(d) total effects of traits on relative growth, reflecting extended performance gradients (sum of all indirect \& direct effects of traits on growth)

$\begin{array}{rrrrr}\text { Relative growth } & -0.047 & \mathbf{- 0 . 0 6 1} & \mathbf{0 . 0 3 9} & 0.014 \\ & (0.024) & \mathbf{( 0 . 0 2 0 )} & \mathbf{( 0 . 0 2 0 )} & (0.019)\end{array}$

This article is protected by copyright. All rights reserved. 


\section{Table 3: Path coefficients detailing effects of shape (RW1V and RW2V) on growth within samples of brown and silver Arctic charr morphs from the Icelandic lake}

Vatnshlídarvatn, and z-tests comparing effects between morphs. Standardised path coefficients (a), compound path coefficients (b), effects via trophic proxies (c), and total effects (d) from the path diagram relating shape (Fig. 2) to relative growth (Fig. 1a), with covariates of age, sex, residual gonad mass, and fork length. Coefficients are displayed (standard errors in parentheses) except z-test columns which display $p$-values. Bolded values are significant at $p=0.05$ (significant path coefficients differ from zero; z-test significance indicates morph coefficients differ). Growth was relativised by dividing by mean growth within morph. Greater $\delta 13 \mathrm{C}$ indicates greater resource breadth in Vatnshlíđarvatn, greater $\delta 15 \mathrm{~N}$ indicates higher trophic level, Diplostomum are flukes with snail intermediate hosts, Diphyllobothrium are tapeworms with copepod intermediate hosts. $\delta 13 \mathrm{C}$ and $\delta 15 \mathrm{~N}$ are included separately in (a) for univariate coefficients. Because $\delta 13 \mathrm{C}$ and $\delta 15 \mathrm{~N}$ together produce an estimate of resource use, in compound path coefficients (b) they are not considered independently.

brown

$\delta 13 \mathrm{C}$

$\delta 15 N$

Diplo.

Diph.

RW1

RW2

(a) path coefficients, detailing

$\begin{array}{ccc}\delta 13 C & -0.020 & 0.024 \\ & (0.124) & (0.122) \\ \delta 15 \mathrm{~N} & -0.015 & -0.172 \\ & (0.131) & (0.129)\end{array}$

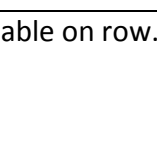

Bottom row

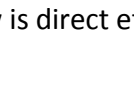

\section{Diplostomum}

$\begin{array}{cc} & \mathbf{( 0 . 0 9 7} \\ \text { Diphyllobothrium } & 0.129\end{array}$

\subsection{0}

$-0.084$

(0.097)

(0.096)

0.067

$-0.048$

(0.077) (0.073)

$-0.224$

$-0.062$

0.167

(0.129)

Relative growth $\quad 0.088$

$$
\text { (0.128) }
$$

(0.102)

(0.097)

$-0.034$

$-0.064$

0.051

(0.046)

(0.045)

(0.036)

$(0.034)$

(0.045)

0.006

$-0.033$

(0.056) (0.049)

$-0.010 \quad-0.078$

(0.074) (0.065)

$0.121-0.238$

(0.049) (0.043)

$0.034-0.188$

$\begin{array}{llll}(0.073) \quad(0.064) \quad(0.062) & (0.047)\end{array}$

$\begin{array}{llll}0.092 & -0.084 & -0.064 & 0.014\end{array}$

$\begin{array}{lll}-0.084 & -0.064 & 0.014\end{array}$

(0.023) (0.021) (0.016) silver

z-test

RW2

p-values

0.6910 .665

$0.973 \quad 0.515$

$0.170 \quad 0.143$

$0.522 \quad 0.801$

$\begin{array}{ll}-0.061 & 0.008\end{array}$

$0.939 \quad 0.323$

This article is protected by copyright. All rights reserved. 
(b) compound path coefficients. Summaries of indirect effects of traits (columns) on relative growth via trophic pathways (rows)

Effect on relative growth via:

\begin{tabular}{|c|c|c|c|c|c|c|}
\hline isotopes & 0.001 & -0.010 & -0.002 & 0.001 & 0.781 & 0.385 \\
\hline & $(0.010)$ & $(0.012)$ & $(0.004)$ & $(0.004)$ & & \\
\hline \multirow[t]{2}{*}{ isotopes via Diphyllobothrium } & 0.000 & 0.000 & 0.000 & 0.000 & 1.000 & 1.000 \\
\hline & $(0.000)$ & $(0.001)$ & $(0.000)$ & $(0.000)$ & & \\
\hline \multirow[t]{2}{*}{ isotopes via Diplostomum } & 0.000 & 0.000 & 0.000 & 0.001 & 1.000 & 0.480 \\
\hline & $(0.000)$ & $(0.001)$ & $(0.001)$ & $(0.001)$ & & \\
\hline \multirow[t]{2}{*}{ Diplostomum } & 0.007 & -0.002 & -0.007 & 0.015 & 0.268 & 0.018 \\
\hline & $(0.012)$ & $(0.004)$ & $(0.004)$ & $(0.006)$ & & \\
\hline \multirow[t]{2}{*}{ Diphyllobothrium } & 0.001 & -0.001 & 0.000 & -0.002 & 0.808 & 0.907 \\
\hline & $(0.004)$ & $(0.008)$ & $(0.001)$ & $(0.003)$ & & \\
\hline \multirow[t]{2}{*}{ Relative growth } & 0.008 & -0.014 & -0.010 & 0.015 & 0.318 & 0.088 \\
\hline & (0.017) & $(0.015)$ & $(0.006)$ & $(0.008)$ & & \\
\hline
\end{tabular}

(d) total effects of traits on relative growth, reflecting extended performance gradients (sum of all indirect \& direct effects of traits on growth)

$\begin{array}{rrr}\text { Relative growth } & \mathbf{0 . 0 9 6} & -0.048 \\ & \mathbf{( 0 . 0 4 6 )} & (0.045)\end{array}$

$0.082-0.069$

$0.789 \quad 0.675$

This article is protected by copyright. All rights reserved. 
Table 4: Size-dependent mortality within cohorts from 2014 to 2016 for Arctic charr morphs from two Icelandic lakes, Thingvallavatn and Vatnshlídarvatn. Estimated mean cohort fork length before selection, after selection, directional selection differentials $(S)$, with bolded values significant at $\mathrm{p}<0.05$ (t-test), standard errors, and p-values. Age comparisons are within cohorts of each morph, using back-calculated length at a given age to estimate the difference between mean length of the cohort before selection (caught at younger age) to that of individuals that survived selection (caught at older age).

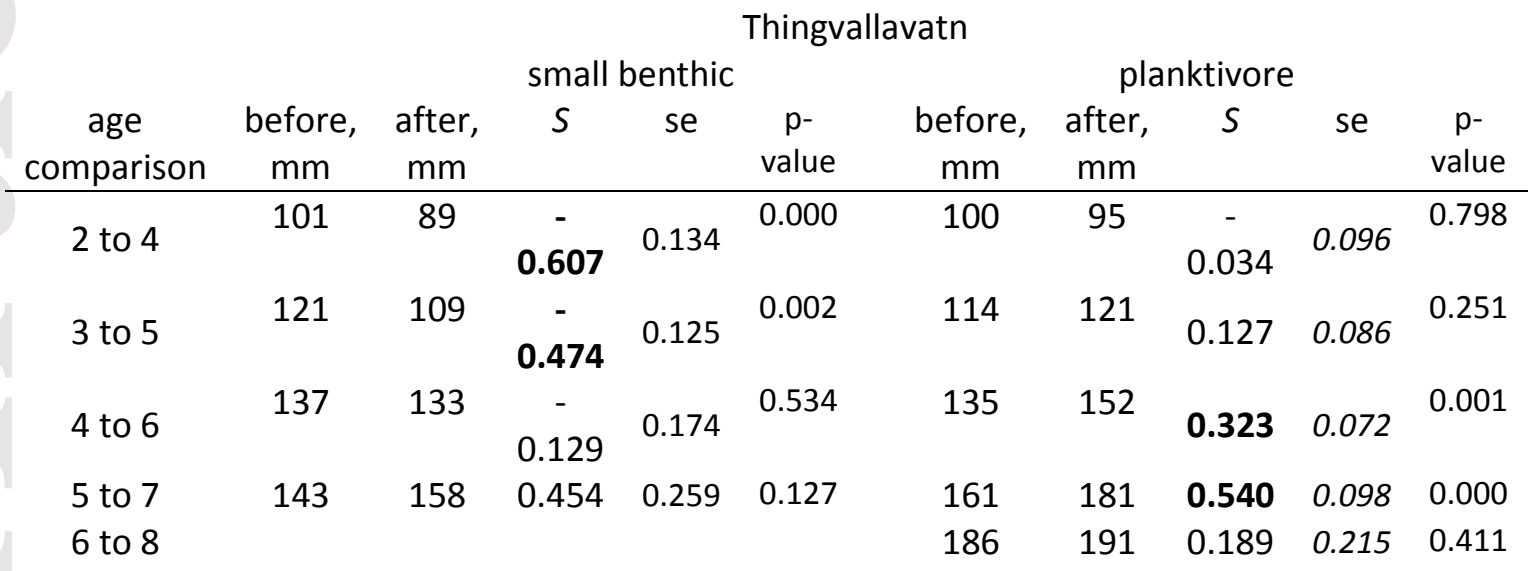

\begin{tabular}{|c|c|c|c|c|c|c|c|c|c|c|}
\hline \multirow[b]{3}{*}{$\begin{array}{c}\text { age } \\
\text { comparison }\end{array}$} & \multicolumn{10}{|c|}{ Vatnshlíđarvatn } \\
\hline & \multicolumn{5}{|c|}{ brown } & \multicolumn{5}{|c|}{ silver } \\
\hline & $\begin{array}{c}\text { before, } \\
\mathrm{mm}\end{array}$ & $\begin{array}{c}\text { after, } \\
\mathrm{mm}\end{array}$ & $S$ & se & $\begin{array}{c}p- \\
\text { value }\end{array}$ & $\begin{array}{c}\text { before, } \\
\mathrm{mm}\end{array}$ & $\begin{array}{c}\text { after, } \\
\mathrm{mm}\end{array}$ & $S$ & se & $\begin{array}{c}p- \\
\text { value }\end{array}$ \\
\hline 2 to 4 & 116 & 124 & 0.097 & 0.121 & 0.555 & 112 & 140 & 0.510 & 0.049 & 0.000 \\
\hline 3 to 5 & 149 & 153 & 0.205 & 0.289 & 0.511 & 169 & 191 & 0.473 & 0.059 & 0.000 \\
\hline 4 to 6 & 170 & 170 & 0.021 & 0.345 & 0.949 & 209 & 224 & 0.583 & 0.107 & 0.000 \\
\hline
\end{tabular}

This article is protected by copyright. All rights reserved. 

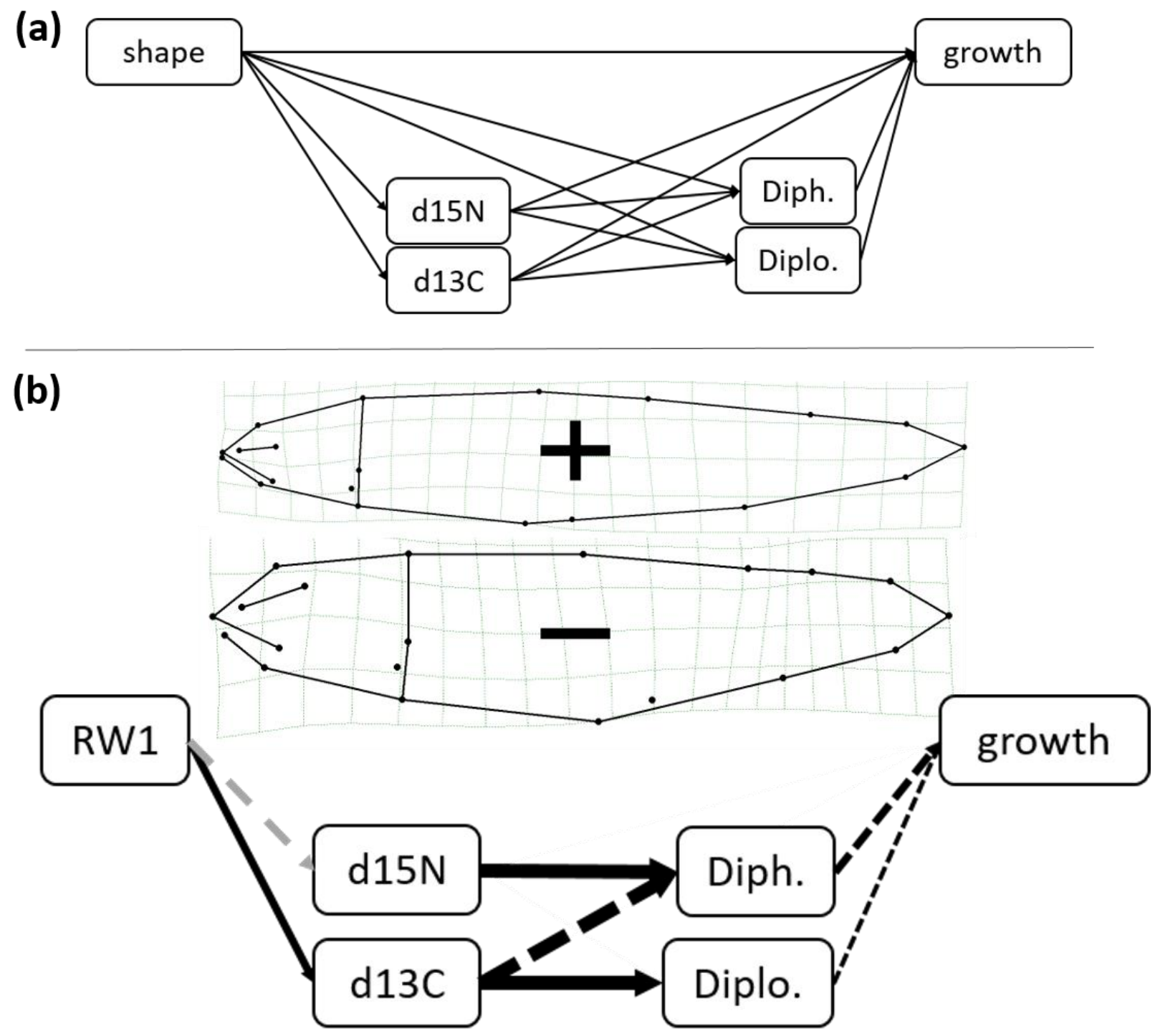

Figure 1: Path diagrams illustrating (a) all path coefficients incorporated into models, and (b) effects estimated for the first relative warp of the planktivore Arctic charr morph from

Thingvallavatn, Iceland. In (a) arrows connecting shape, stable isotopic signatures (d13C, d15N), and parasite infections (Diph., Diplo.), show how shape could indirectly affect growth via trophic pathways. The arrow directly connecting shape and growth accounts for non-trophic effects of shape on growth. The sum of all pathways reveals the total effects of shape on growth. (b) Wireframe depictions and path diagram of Thingvallavatn first relative warp (RW1) summarising effects of shape variation on growth in planktivore charr. Diph refers to Diphyllobothrium, Diplo to Diplostomum, $\delta 13 \mathrm{C}$ and $\delta 15 \mathrm{~N}$ are stable isotopic signatures, and growth is relative back-calculated growth over one year. Solid lines depict positive relationships, dashed lines negative, with thickness reflecting the magnitude of path coefficients. Black lines are significant at $p<0.05$, grey lines are p $<0.10$, other path coefficients omitted; see Tables 2 - 3 (RW1 and RW2) or Tables S2 - S5 (all shape variables) for full details. Notably, effects of stable isotopic signatures on growth are mediated by parasitism, and effects of shape on growth are accounted for by trophic pathways.

This article is protected by copyright. All rights reserved. 

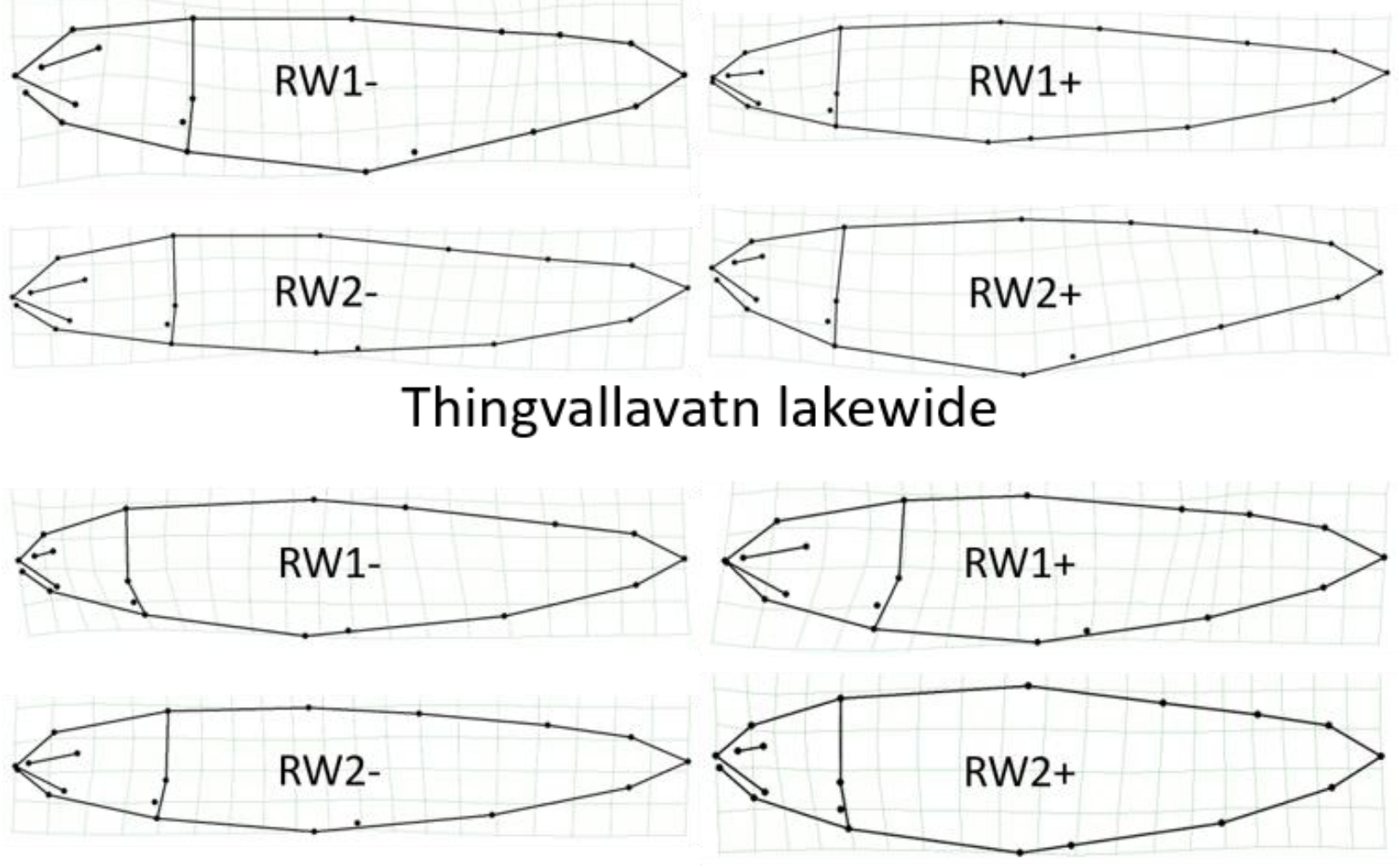

\section{Vatnshlíđarvatn lakewide}

Figure 2: Wireframe representations summarising the first two principal axes of shape variation (RW1, RW2) of Arctic charr morphs from the Icelandic lakes Thingvallavatn and Vatnshlídarvatn. Thingvallavatn RW1T summarises 43.98\%, and RW2T 10.34\%, of lakewide shape variation captured by landmarks. Vatnshlíđarvatn RW1V summarises 31.05\%, and RW2V 19.18\%, of lakewide shape variation captured by landmarks. Wireframe depictions of RW3 to RW5 are in supplementary materials (Fig. S3)

This article is protected by copyright. All rights reserved. 